\title{
AC 2010-1264: NATIONAL DISSEMINATION OF LITEE CASE STUDIES: A MODEL
}

\section{Ashley Clayson, Laboratory for Innovative Technology and Engineering Education}

Ashley Clayson is a graduate student in Technical and Professional Communication at Auburn University. She has worked with the Laboratory for Innovative Technology and Engineering Education (LITEE) for the past year, and she is Editorial Assistant for the Journal of STEM Education: Innovations and Research.

\section{P K Raju, Auburn University}

Dr. Raju is the Thomas Walter Distinguished Professor of Mechanical Engineering at Auburn University. He has made significant research contributions in acoustics, noise control, nondestructive evaluation engineering education, and technology transfer, resulting in award-winning and significant breakthroughs. He has received a total of $\$ 8.4$ million in funding, including grants from industries, the United Nations, the National Science Foundation, NIST, $\mathrm{NIH}$, EDA and other U.S. and international agencies. He has published 17 books, 8 book chapters and 160 papers in journals and conference proceedings. He has received several awards for his teaching, research and outreach work from NASA, NSF, ASME, ASEE and others. He served as a United Nations and UNDP expert. He has been invited as a keynote speaker at several conferences organized in USA, France, Germany, Chile, and Singapore and in India.

Dr. Raju has been a pioneer in introducing the case study methodology. He is the Director of the Laboratory for Innovative Technology and Engineering Education (LITEE), which he co-founded with Dr. Chetan Sankar, of Auburn University’s College of Business. LITEE is recognized nationally and internationally for its work in developing and disseminating cases studies that bring real world issues into classrooms. He also serves as the Director of the Auburn Engineering Technical Assistance Program (AETAP), which received the prestigious Partnership for Innovation Grant from the National Science Foundation. He has been active in ASME in leadership roles at the local, regional, and national levels. He is a Fellow of the American Society for Engineering Education, a Fellow of the American Society of Mechanical Engineers, a Fellow of the Institution of Engineers India, and a Fellow of the Acoustical Society of India. He is a member of the Acoustical Society of America, Institute of Noise Control Engineering and the International Institute of Acoustics and Vibration He is the Editor in Chief of the Journal of STEM Education: Innovations and Research (www.jstem.org) and serves on the Editorial Board of the Annals of Research in Engineering Education published by the National Academy of Engineering.

\section{Chetan Sankar, Auburn University}

Chetan S. Sankar is a Professor of Management at the Auburn University's College of Business. He received his Ph.D. from the Wharton School, University of Pennsylvania and has worked at Temple University and AT\&T Bell Laboratories. His research interests focus on researching innovative practices to integrate teaching, research, and outreach both locally and globally (www.litee.org). He has published more than 150 papers in journals, book chapters, and conference proceedings. He has won awards for research and teaching from the Society for Information Management, iNEER, Decision Sciences Institute, American Society for Engineering Education, Frontiers in Education, and the Project Management Institute. He is the editor of the Decision Sciences Journal of Innovative Education (www.dsjie.org). He has been the principal or co-principal investigator of several grants from the National Science Foundation budgeted at more than \$2.2 million and a grant from the Economic Development Administration. He can be reached atsankacs@auburn.edu. 


\title{
National Dissemination of LITEE Case Studies: A Model
}

\begin{abstract}
One of the primary functions of the Laboratory for Innovative Technology and Engineering Education at Auburn University is to use case study methodology to develop innovative classroom materials that will engage students intellectually and expose them to real-world problems in engineering and business. The cases are developed by undergraduate and graduate students working closely with engineering and business professors and industry professionals to gain a full understanding of the problems, options, and ultimate solutions in a given case. They are available on the internet at www.liteecases.com. Case studies have proven to improve students' higher-order cognitive skills and improve their attitude toward engineering studies.

In order to disseminate these case studies in other institutions, the directors of LITEE obtained NSF grant \# 0442531. Using this grant, the directors invited professors at colleges and universities around the nation to compete for funds to use the cases in their classrooms. Twentysix professors were chosen to incorporate the cases into their curriculums, conduct research regarding the cases' effectiveness, and publish the findings through articles in appropriate publications. So far, the Journal of STEM Education: Innovations and Research has accepted seven of these papers for publication in special issues and will continue to publish special issues until each professor's findings have been detailed.

Disseminating the case studies in this way allows several things to happen. First, the educators involved are funded to experiment with case study methodology and pedagogy in their classrooms. Thereby, they gain first-hand experience in use of innovative instructional materials. Second, writing a research article motivates them to use a research methodology in the implementation process. Thirdly, students in these institutions are provided with an opportunity to experience different methods of learning and are given the opportunity to grapple with real world problems and learn from the experience of industry professionals. This paper details this dissemination research process.
\end{abstract}




\section{Introduction: Need for Innovative Instructional Materials in Engineering}

A paradigm shift is taking place in engineering and technology education. Driven by the National Science Foundation (NSF), the Accreditation Board for Engineering and Technology Education (ABET), the changing expectations of employers, emerging knowledge in cognitive theory and educational pedagogy, improvements in information and instructional technologies, and many other forces, the approach to engineering education is shifting dramatically. The new approach assumes that every student can learn with the assistance of effective new strategies and practices that increase learning. Instructors are expected to build upon students' prior experiences, promote high expectations within a supportive climate, and encourage inquiry and the excitement of discovery, in addition to embedding communication and teamwork, critical thinking, and life-long learning skills into the learning experience ${ }^{14}$. Active, integrative projectbased learning is needed to replace the passive lecture-based instruction that is so common in our classrooms ${ }^{9,19,7,15}$. Engineering students are increasingly being asked by potential employers to demonstrate "soft" skills (such as problem solving, communication, and teamwork skills) in addition to their "hard" technical skills. Reflecting these expectations, the Accreditation Board for Engineering Education adopted new accreditation criteria, which identify in Criterion 3 (a) through (k), eleven outcomes expected of engineering graduates'

Faculty and administrators across the nation have come to reassess the values of various instructional methods, seeking the best ways to instruct students not only in technical skills and information, but also in higher-order cognitive skills like problem-solving, critical thinking, reasoning, decision making, and communicating. As the need to impart these skills to students become more imperative, so does the need to find pedagogies that will most effectively develop them for the widest range of students. The need for innovative educational programs has been heavily emphasized in the engineering field in the past several years; describing one such program, Sudhir Mehta and Zhifeng Kou of North Dakota State University emphasize: "Such pedagogies are absolutely essential in the global economy, because they prepare students who can start contributing quickly at their work places, as well as in the society" ${ }^{2}$. Brumm et al, describing a program at Iowa State University, also state: “...pedagogy that attempts these types of innovations has the power to excite our students to see their classrooms as places where powerful and practical lessons are learned about their chosen profession..." ${ }_{3}$. While each of these programs focus on different outcomes for students, they all agree that new approaches and pedagogical experimentation in the classroom are absolutely imperative for advancement in engineering education.

In the past decade, case studies have been used more frequently in engineering classrooms as research has shown that the case study methodology provides more benefits to students compared to traditional lecture methodology ${ }^{11,18}$. Drs. Raju and Sankar from Auburn University, who have been involved in case study research for over a decade, wanted to find a way to more effectively disseminate the case study methodology into classrooms across the nation so that ever more students would benefit from the instruction. This paper details the process they followed, provides some examples of the research that has resulted from this project, and examines the results of conducting such a project. 


\section{History of LITEE}

The Laboratory for Innovative Technology and Engineering Education at Auburn University has worked for the last fourteen years to develop case studies. LITEE was founded in 1996 by Drs. P.K. Raju and Chetan Sankar, both of Auburn University. Dr. Raju is from the College of Engineering and Dr. Sankar is from the College of Business. The professors started working together on case study projects sponsored by the Thomas Walter Center for Technology Management at Auburn University and the National Science Foundation.

Raju and Sankar worked with Alabama Power to create their first case study, the Della Steam Plant Case Study, in 1996, and began introducing it into engineering classrooms. They developed the case study in an effort to introduce real world issues in engineering classes, using case studies from the Harvard Business School as a model. The feedback from the students was so positive that these researchers went to NSF with the idea that they could expand this research, and LITEE was born. Fourteen years later, LITEE has developed numerous multimedia case studies for use in engineering and business classrooms. Eighteen of these case studies are currently available online at www.liteecases.com.

Evaluation results from students using these case studies at various universities have shown that the case studies improve the higher-level cognitive skills of the students and encourage them to pursue engineering as a field of study ${ }^{11}$. Studies have shown that women and minorities respond particularly well to the case study approach ${ }^{18,11}$. LITEE case studies introduce engineering students to the complexity of real-world problems and demonstrate how engineering companies work in the information age. Though this initial research indicates that LITEE case studies are beneficial to students, Drs. Raju and Sankar wanted to know more. They wanted to examine the effects of case studies in a variety of settings-how much greater understanding of the impact of case studies on student learning could be gained if the case studies were used in classrooms across the nation? This research question led them to develop the LITEE National Dissemination Grant Competition Project, sponsored by NSF DUE \#0442531.

\section{Dissemination Process}

\subsection{Initial Steps}

First, Drs. Raju and Sankar developed a proposal to the National Science Foundation. Their goal was to obtain funding that would allow them to disseminate the LITEE case studies and facilitate research through professors across the nation. In their grant proposal to NSF, the professors explained the possibilities that conducting such research held--that by getting the case studies into classrooms across the country, their effectiveness could be more thoroughly measured.

During the first two years of the project, they disseminated information about the case studies by conducting regional and national workshops that detailed the case studies' benefits ${ }^{17}$. Even though these were well attended, follow-up research showed that faculty who attended the workshops did not necessarily implement the case studies in their classrooms. They appreciated the new methodology, but were reluctant to introduce it in their classrooms, feeling that their courses were unique. 
Therefore, the directors of LITEE had to find other means of effectively disseminating the case studies. They applied for and received a supplemental grant that would allow the researchers to add multiple implementations of the case study methodologies in different institutions to the project. They created a web site in order to distribute the case studies and developed a grant competition in order to create incentive for professors to use the cases in their classrooms.

First, the researchers sent out a call for proposals to faculty members interested in integrating LITEE case studies into their classrooms. The researchers requested participating faculty to use a LITEE case in one of their courses during 2009 to supplement traditional lecture material.. The instructors were also expected to use research methods to evaluate the impact of the case study methodology on the students' cognitive skills and attitudes. The LITEE website provided preand post-survey instruments that the instructors could use (see Appendix A for these instruments; they are also available at www.litee.org). An instructor's support system was also made available for use with these case studies in the classroom.

Finally, after implementing the case studies in their classes and using a research method to evaluate the case studies' impact, the chosen participants would be required to develop a journal article based on their research and submit it for publication. The Journal of STEM Education: Innovations and Research would provide an appropriate outlet for publication.

The call for proposals explained that selected proposals would receive funding for conducting the research, in the amount of $\$ 1,000$ or $\$ 2,000$ (because funds were limited). Thirty faculty members submitted a one-page proposal, and the LITEE directors found that 26 of them had strong technical merit and the potential for broader impacts. Table 1 (next page) summarizes the faculty members, institutions, and the courses in which they intended to use the LITEE case studies. In addition, these faculty members have expressed strong interest in developing articles based on their implementation experiences. 


\begin{tabular}{|c|c|c|c|}
\hline Instructor & University & Students & Course \\
\hline James M. Conrad & $\begin{array}{l}\text { University of North Carolina at } \\
\text { Charlotte }\end{array}$ & 30 & ECGR6185: Advanced Embedded Systems \\
\hline Qiang Le & Hampton University (HBCU) & 20 & Introduction to Engineering \\
\hline Ellen Lackey & University of Mississippi & 20 & ME 324: Introduction to Design \\
\hline Victor W. Mbarika & Southern University (HBCU) & 35 & $\begin{array}{l}\text { MGMT 305: Management Information } \\
\text { Systems }\end{array}$ \\
\hline Karl E. Burgher & $\begin{array}{l}\text { Missouri University of Science } \\
\text { and Technology }\end{array}$ & $30+$ & Introduction to Project Management \\
\hline Patrick E. Connolly & Purdue University & $30-35$ & $\begin{array}{l}\text { Computer Graphics Technology, Product Data } \\
\text { Management }\end{array}$ \\
\hline Judith R. Pearse & University of Maine at Orono & $30-50$ & Engineering Project Management, EET 386 \\
\hline Eugene Rutz & University of Cincinnatti & 20 & Engineering Your Future \\
\hline LaKami Baker & Auburn University & 45 & Managing Entrepreneurial Startups \\
\hline Steve Brown & Washington State University & 50 & ME 416 capstone design \\
\hline Eli H. Fini & $\begin{array}{l}\text { North Carolina A \& T State } \\
\text { University (HBCU) }\end{array}$ & 20 & CIEN482: Construction Engineering \\
\hline Kemper Lewis & University at Buffalo--SUNY & $170-190$ & $\begin{array}{l}\text { MAE277: Introduction to Mechanical and } \\
\text { Aerospace Engineering Practice }\end{array}$ \\
\hline W. A. Hornfleck & Lafayette College & 30 & $\begin{array}{l}\text { VaST 241, a "Values and Science \& } \\
\text { Technology" core curriculum course }\end{array}$ \\
\hline $\begin{array}{l}\text { Mahour Mellat- } \\
\text { Parast }\end{array}$ & $\begin{array}{l}\text { University of North Carolina- } \\
\text { Pembroke }\end{array}$ & 30 & Operations Management (MGT4410) \\
\hline Peter A. Stanwick & Auburn University & 60 & Strategic Management (MNGT 4800) \\
\hline Kenneth J. Reid & Ohio Northern & 100 & Freshman Engineering 2 (GE 105) \\
\hline Raghu Echempati & Kettering University & 20 & $\begin{array}{l}\text { Introductory Mechanical Engineering Design } \\
\text { course }\end{array}$ \\
\hline Sung Shim & Seton Hall University & 20 & $\begin{array}{l}\text { Analytical Methods and Information Systems } \\
\text { for Business }\end{array}$ \\
\hline $\begin{array}{l}\text { Muge Mukaddes } \\
\text { Darwish }\end{array}$ & Texas Tech University & 100 & $\begin{array}{l}\text { GTEC } 3412 \text { Fluid Mechanics, CTEC } 4343 \\
\text { Safety and Health }\end{array}$ \\
\hline S. Keith Hargrove & $\begin{array}{l}\text { Morgan State University } \\
\text { (HBCU) }\end{array}$ & $20-30$ & $\begin{array}{l}\text { IEGR 200: Introduction to Industrial } \\
\text { Engineering and Computers }\end{array}$ \\
\hline Vijaya Narapareddy & University of Denver & 30 & $\begin{array}{l}\text { MGMT 3800: Undergraduate Capstone } \\
\text { Strategy Course }\end{array}$ \\
\hline $\begin{array}{l}\text { James Patrick } \\
\text { Abulencia }\end{array}$ & Manhattan College & 30 & Senior Unit Operations Laboratory \\
\hline Jerry K. Sherrod & $\begin{array}{l}\text { Pellissippi State Technical } \\
\text { Community College }\end{array}$ & $20-22$ & $\begin{array}{l}\text { Windows Professional and/or Windows } \\
\text { Server class }\end{array}$ \\
\hline Richard E. Miller & $\begin{array}{l}\text { Oklahoma Christian } \\
\text { University }\end{array}$ & 10 & $\begin{array}{l}\text { ELEC-3613: Electromagnetic } \\
\text { Fields }\end{array}$ \\
\hline Raghu Pucha & $\begin{array}{l}\text { Georgia Institute of } \\
\text { Technology }\end{array}$ & 40 & $\begin{array}{l}\text { ME 1770: "Introduction to Engineering } \\
\text { Graphics and Visualization" }\end{array}$ \\
\hline \multirow[t]{2}{*}{$\begin{array}{l}\text { Matthew J. } \\
\text { Franchetti }\end{array}$} & University of Toledo & 140 & $\begin{array}{l}\text { MIME 1010: Professional Development for } \\
\text { Engineers }\end{array}$ \\
\hline & Total: & 850 & \\
\hline
\end{tabular}


Table 1: Faculty Members Interested in Implementing LITEE Case Studies in their Classrooms

\subsection{First Studies Completed}

Several of the instructors who were chosen to participate in this project have completed their research and submitted their findings to an appropriate research outlet. The Journal of STEM Education: Innovations and Research (www.jstem.org), also called JSTEM, has provided just such an outlet for several of the participants. Ashley Clayson, Editorial Assistant for JSTEM, along with Dr. P.K. Raju, Editor-in-Chief, is coordinating the submission, review, and publication process for these articles. The journal has already accepted seven articles based upon this research, and we currently have six more papers in the review process. Each of the papers accepted will be published in special issues of JSTEM which deal specifically with the Case Study Dissemination Project. The first of these special issues, which contains four of the seven accepted papers, was published in February 2010 and is available for viewing at www.jstem.org.

The title and abstract of each of the accepted papers, as written by their authors, is provided below. After the abstracts, we provide a summary of the various methodologies used thus far in the dissemination process, and an evaluation of the findings of these studies.

\section{The Application of an Engineering Design and Information Systems Case Study in a Senior Level Product Data Management Course, Patrick Connolly Case Study Used: Yuquiyu Motors Case Study}

This study examines the use of an engineering design and information systems case study over a three week period in a senior level class covering the topics of product data management (PDM) and product lifecycle management (PLM). Students that have taken the course in the past have struggled with the sometimes nebulous and difficult to conceptualize concepts of both PDM and PLM. It was hoped that the application of a case study of this nature would help clarify the principles of these important topics.

Students were assigned in groups to various roles as defined in the case, as well as given a specific scenario to examine. Their task was to analyze the case from a PDM/PLM perspective and provide solutions and recommendations that would resolve the issues their group/role faced. Upon conclusion of the project, the students were given a survey that caused them to reflect on the case and its possible benefits as an educational method.

The results were promising, and showed that the students found the case to be very helpful in learning and understanding the principles of PDM/PLM. Mean scores from Likert instrument questions as well as comments from open-ended questions are shared in the paper. Although the study was limited to one class $(n=18)$ of students in a specific topic of study, the implications for instruction strongly support the use of case studies and practical scenarios in technology education ${ }^{4}$.

2. Evaluation of the Effectiveness of the Integration of a LITEE Case Study for a Freshman Level Mechanical Engineering Course at The University of Toledo, Matthew Franchetti Case Study Used: Lorn Manufacturing Case Study 
The purpose of this paper is to report the findings of the integration of a manufacturing case study to a freshman level mechanical engineering course at The University of Toledo. The approach to integrate this case study into the class was completed via weekly assignments analyzing the case, small group discussion, and weekly group discussion.

The key findings from study demonstrate that the integration of the case study into this course improved the students' attitudes towards engineering, higher-order cognitive learning, self-efficacy, ease of learning the subject matter, team working and communication skills. In addition, the retention rates in course improved by $4.5 \%$ and the final average grade improved by $3.3 \%$ over the previous year. The implications of these findings to educators are very positive. Based on student comments, the integration of the case study increased retention of the material and their satisfaction with the course and offered another mechanism for students to study and relate concepts of the course and understand its role in engineering and life. This, in turn, increased the students' confidence in engineering and should help to improve graduation rates. One key contribution from this study demonstrates that the case study method can effectively be applied in engineering courses with positive results ${ }^{8}$.

\section{Use of the LITEE Lorn Manufacturing Case Study in a Senior Chemical Engineering Unit Operations Laboratory, Nithin Susan Abraham, James Patrick Abulencia Case Study Used: Lorn Manufacturing Case Study}

This study focuses on the effectiveness of incorporating the Laboratory for Innovative Technology and Engineering Education (LITEE) Lorn Manufacturing case into a senior level chemical engineering unit operations course at Manhattan College. The purpose of using the case study is to demonstrate the relevance of ethics to chemical engineering students by addressing real-life ethical problems found in the workplace.

The selected LITEE case study, which involves a maintenance worker who experiences an accident during a routine procedure, helps transfer the theory behind ethics into practice, highlights the importance of team work, and prepares the students to evaluate and present an assigned position in the case to a panel of two attorneys. The assignment also helps narrow down the question of where to incorporate ethics into the overcrowded chemical engineering curriculum. Student feedback indicates that the unit operations laboratory course is not the best place to insert the case study. Implications for future research suggest for an engineering ethics course, which can allow for ethics to be taught in an in-depth and more effective manner.

Finally, the case study helps educators realize that students should have experiences outside of their comfort zone by learning to communicate technical concepts in a comprehendible manner to a real audience and in a realistic atmosphere. The limitations of this study further strengthens the notion of how much of a challenge it is for educators to teach ethics to engineering students due to the fact that it may or may not be possible to change a person's ethical values . 
4. Incorporating a Real World Case Study into the Syllabus of a Senior Construction Engineering Course, Eli Fini

Case Study Used: Mauritius Auditorium Design Case Study

This paper investigates the effect of bringing real world case studies on college students' self efficacy, their confidence, and their motivation toward an engineering field. It was found that working with real cases increases student's motivation and maximizes their learning by becoming personally committed to course and program goals. As a result of trying to address the problem statement and analyze the assigned case, students were inspired to learn the theory and put together their acquired knowledge. It was also found that the learning process was facilitated by students feeling a need to learn more about their subject to be able to tackle real world's problems .

\author{
5. Utilizing Multimedia Case Studies to Teach the Professional Side of Project \\ Management, Cassandra C. Elrod, Susan L. Murray, Barry B. Flachsbart, Karl E. \\ Burgher, and Drew M. Foth \\ Case Study Used: Superstar Case Study
}

This research was conducted to evaluate the effectiveness of using a LITEE multimedia case study to teaching concepts in engineering courses. The LITEE Superstar case study was implemented in an engineering Project Management course. Numerous surveys regarding student expectations, outcomes, and attitudes were collected and results are presented herein. Overall, the study provided evidence that the students felt that the LITEE case study added value to the course via the different methods of teaching material, aided in the understanding of the project selection process, and ultimately helped them be successful in their course project which was conducted for a real rural Missouri city. The data was unable to be tracked on a per student basis; this yields areas for future research to track individual student improvement and attitudes. This research provides evidence that using multimedia case studies, such as the case studies published by LITEE, are effective and well received by engineering students in their courseworks.

6. A Multi-Experimental Study on the Use of Multimedia Instructional Materials to Teach Technical Subjects, Victor Mbarika, Emily Bagarukayo, Vineeta Hingorani, Sandra Stokes, Mathieu Kourouma, and Chetan Sankar Case Studies Used: Crist Power Plant Case Study, AUCNET USA Case Study, Chick-fila Case Study

A review of "social experiments" with adoption of multimedia-based technologies in Europe has been reported. But, there has been limited discussion on the value of multimedia instructional materials in technical disciplines. This study combines results from experiments carried out over a period of three years with multiple audiences - IT managers and students majoring in business and engineering -- to examine if multimedia case studies do improve perceived Higher Order Cognitive Skills (HOCS) and if so, what accounted for such improvements. Among all the experimental groups involved in this study, it was found that participants reported improvements in perceived HOCS, self reported learning, learning interest, challenges to their thought process, and learning from others ${ }^{10}$. 


\section{Using Multimedia Content to Present Business Ethics: An Empirical Study, Peter}

Stanwick Case Study Used: STS-51 L (Challenger) Case Study

The purpose of this study is to empirically examine whether presenting a multimedia case study enhances the learning experience of students in an undergraduate management class. A questionnaire was administered before and after the presentation of the case study and the results showed that the multimedia case did indeed enhance the learning experience of the students. The students' attitudes related to management and business ethics constructs were also positively impacted. The results demonstrated that multimedia case studies are valuable tools that can be used by instructors to develop a more interactive learning environment. The study extends previous research by demonstrating that students' performance can improve by using a multimedia case study from both a management and business ethics perspective. There are a number of limitations of this study including the relatively small sample size, the administration of the questionnaire in only one class and the inability to compare the impact of the multimedia case study with a control group ${ }^{20}$.

\subsection{Synthesis and Analysis of the Articles}

These first seven articles provided us with sufficient information to synthesize and analyze the findings presented in these papers.

\subsubsection{Summary of Methods}

A main part of the grant competition was using a research method to evaluate the case studies. LITEE provided survey instruments for use through its website (see Appendix A), and several of the grantees used them in their research. Some professors adapted the provided surveys, adding or removing items in order to serve their specific research purposes; some professors utilized additional survey instruments, while other professors substituted their own survey instruments. Some of the grantees specified the tests they used to analyze the data collected, like ANOVA or t-tests. The table below summarizes the instruments and analysis methods of each of the above seven papers.

\begin{tabular}{|l|l|l|l|l|l|l|l|}
\hline Paper & $\begin{array}{l}\text { LITEE } \\
\text { Survey }\end{array}$ & $\begin{array}{l}\text { Additional } \\
\text { Survey }\end{array}$ & $\begin{array}{l}\text { Quantitative } \\
\text { Questions }\end{array}$ & $\begin{array}{l}\text { Qualitative } \\
\text { Questions }\end{array}$ & Pre & Post & $\begin{array}{l}\text { Analysis } \\
\text { Method }\end{array}$ \\
\hline 1 & Adapted & & 20 & 8 & $\mathrm{X}$ & $\mathrm{X}$ & $\begin{array}{l}\text { Not } \\
\text { specified }\end{array}$ \\
\hline 2 & Used & & 36 & & $\mathrm{X}$ & $\mathrm{X}$ & $\begin{array}{l}\text { Not } \\
\text { specified }\end{array}$ \\
\hline 3 & & Used & 12 & & & $\mathrm{X}$ & $\begin{array}{l}\text { Not } \\
\text { specified }\end{array}$ \\
\hline 4 & Adapted & & 23 & $\begin{array}{l}\text { Unspecified } \\
\text { number }\end{array}$ & $\mathrm{X}$ & $\mathrm{X}$ & ANOVA \\
\hline
\end{tabular}




\begin{tabular}{|l|l|l|l|l|l|l|l|}
\hline 5 & Used & Used & 42 & 11 & $\mathrm{X}$ & $\mathrm{X}$ & ANOVA \\
\hline 6 & & Used & 40 & & $\mathrm{X}$ & $\mathrm{X}$ & $\mathrm{t}$-test \\
\hline 7 & Used & & 36 & & $\mathrm{X}$ & $\mathrm{X}$ & $\begin{array}{l}\text { Paired } \\
\text { t-test }\end{array}$ \\
\hline
\end{tabular}

Table 2: Summary of 7 Grantees' Methods

Though each of the authors used different methods of evaluation, the papers show several trends in their research questions. Most authors examined at least some aspect of the following constructs that LITEE case studies claim to impact:

Higher-Order Cognitive Skills (HOCS): Researchers wanted to find whether case studies had an impact on the higher-order cognitive skills of students. These HOCS include problem-solving, analysis, evaluation, and synthesis of material. Some (FOOTNOTES) compared the gains in HOCS of different demographic groups (separated by gender or ethnicity, for instance).

Ease of Learning (EL)/Content Learning: Most of the professors whose papers we've received measured how effectively the case studies taught students engineering concepts and how they contributed to students' ease of learning.

Teamworking Skills: Instructors using case studies often assign to groups in order to analyze their case and make their presentations; this lends itself to an examination of how effectively the use of LITEE case studies facilitates the development of good teamworking skills.

Communication Skills: Similarly, because the assignments accompanying case studies often call for various communicative projects, like writing reports or making presentations, many of the professors evaluating the LITEE case studies included in their evaluations an examination of students' communication skills.

Self-Efficacy (SE): Many of the surveys measured issues of self-efficacy, such as students' confidence in their own skills.

\subsubsection{Summary of Findings: Quantitative Data}

The table below summarizes each of the accepted papers' findings in relation to these five constructs. It details whether the studies found that: (a) the studies did not have a statistically significant impact on the construct ("no"), (b) the case studies had a moderate, but not statistically significant impact on the construct ("mod"), or (c) the case studies did have an impact on the construct (yes). It also gives the number of participants in each study, in order to demonstrate the far-reaching effect the national implementation of case studies has had.

\begin{tabular}{|c|c|c|c|c|c|c|c|c|c|c|c|c|c|c|c|c|c|}
\hline \multirow[b]{3}{*}{ Paper } & \multirow[b]{3}{*}{ Students } & \multirow[b]{3}{*}{ Case } & \multicolumn{15}{|c|}{ Constructs } \\
\hline & & & \multicolumn{3}{|c|}{ HOCS } & \multicolumn{3}{|c|}{ EL/Content } & \multicolumn{3}{|c|}{ Team } & \multicolumn{3}{|c|}{ Comm. } & \multicolumn{3}{|c|}{ SE } \\
\hline & & & No & Mod & Yes & No & Mod & Yes & No & Mod & Yes & No & Mod & Yes & No & Mod & Yes \\
\hline 1 & 18 & Yuquiyu & & $\mathrm{X}$ & & & & $\mathrm{X}$ & & $X$ & & & $\mathrm{X}$ & & & $X$ & \\
\hline 2 & 140 & Lorn & & & $X$ & & & $\mathrm{X}$ & & & $\mathrm{X}$ & & & $\mathrm{X}$ & & & $X$ \\
\hline
\end{tabular}




\begin{tabular}{|l|l|l|l|l|l|l|l|l|l|l|l|l|l|l|l|l|l|}
\hline 3 & & Lorn & & & X & & & X & & & & & & & & & \\
\hline 4 & & $\begin{array}{l}\text { Mauitius } \\
\text { Audiorium } \\
\text { Design }\end{array}$ & & & X & & X & & & X & & & X & & & X & \\
\hline 5 & & Superstar & X & & & & & X & X & & & X & & & X & & \\
\hline 6 & 357 & $\begin{array}{l}\text { Crist } \\
\text { AUCNET } \\
\text { CFA }\end{array}$ & & & X & & & X & & & X & & & & & & \\
\hline 7 & 53 & STS-51 L & X & & & & & X & X & & & & & X & X & & \\
\hline Total: & & & 2 & 1 & 4 & & 1 & 6 & 2 & 2 & 2 & 1 & 2 & 2 & 2 & 2 & 1 \\
\hline
\end{tabular}

Table 3: Summary of 7 Grantees' findings

The table shows that overall, that case studies do positively impact student learning of these constructs, as discussed in the sections below:

HOCS: Four of the seven studies demonstrated clearly that students do perceive an increase in higher-order cognitive skill development in classrooms where case studies were used. One study seemed to indicate an increase, but the increase was not statistically significant.

Ease of Learning/Content Learning: Six of the seven studies showed that the case studies had an impact on content knowledge and/or ease of learning of the materials, while one study showed a moderate but not statistically significant impact.

Teamworking Skills: Four of the seven studies showed that case studies have a moderate or significant impact on development of teamworking skills in students.

Communication Skills: Four of the seven studies showed that case studies have a moderate or significant impact on development of communication skills in students.

Self-Efficacy: Three of the seven studies showed that students had positive perception of case studies as beneficial to the course or to concepts of self-efficacy.

These results clearly show that students across the nation perceive case studies to be beneficial on several different areas of learning. Most students perceived an increase in higher-order cognitive skills and said that case studies helped them learn course content and concepts; thus, the National Dissemination Project has so far proven successful in disseminating case studies into engineering classrooms and exposing students to their benefits.

\subsection{3: Summary of Findings: Qualitative Data}

Three of the accepted papers also provided some quotes from students that they gathered from qualitative instruments. The qualitative data often provided the grantees a way to more thoroughly understand the quantitative data gained from the surveys. For example, one paper found that "these responses indicate that despite the negative change in means in the quantitative questions in the 'pre-case study' and 'post-case study' survey, the students did have a sense of accomplishment from the course and instructional materials used"5. Most papers indicated that 
students were overwhelmingly positive in their comments; we've excerpted a few of the quotes below:

"It was beneficial in the way that it got me thinking about PDM/PLM without anyone telling me anything. Therefore I could try to understand the PDM/PLM issues on my own" 4 .

"The case studies were helpful. It made us become problem solvers"4.

"The case is very beneficial because it let you tackle real world problems with real buildings and construction site"

"Analysis of open-ended questions both before and after implementing the case showed that students were enthusiastic about having cases in the course. They specifically referred to the ability of the case to provide more practical and hands-on experience about the subject. In addition they mentioned that through cases they can enhance their problem solving skills" 6 .

"The case study added a new element/layer of depth in seeing what happens to the projects after the research is complete",5.

"I practiced breaking down a problem situation and looking at all component aspects of the problem... to make an intelligent decision on how to treat the situation at hand"

Other qualitative evidence was supplied in the papers as well; though occasional negative quotes were presented, the papers made it clear that most students had positive things to say about their case study experiences. This qualitative evidence, coupled with the quantitative data summarized above, indicate that the National Case Study Dissemination Project has so far proven case studies beneficial to students in several areas, and has provided a way to disseminate the cases effectively to a large number of students and classrooms.

\section{Next step}

The next step for this project includes receiving the rest of the papers and publication of the Special Issues. The directors of LITEE have been in close contact with those instructors involved in the project and expect to receive the rest of the research reports shortly. Publication of the Special Issues began in February 2010 and will continue until all research findings from the project have been published.

\section{Benefits of Dissemination and Conclusion}

A dissemination project such as this has several benefits, not just for those involved with LITEE, but for the entire engineering education community. First, the instructors who were involved in the project had the opportunity--and were funded--to experiment with case study methodology and pedagogy in their classrooms. They gained first-hand experience on the use of innovative instructional materials, and had the chance to discover what they liked and did not like about the materials, to adapt them to suit their needs and the needs of their students, and to witness firsthand the benefits to students that case studies can bring. 
Secondly, students in these institutions receive the opportunity to benefit from the case studies. They have the chance to grapple with real world problems and learn from the experience of industry professionals, something that many students do not have the opportunity to do until they are practicing engineers. These students are given the chance to work in teams, thereby developing their communication and teamwork skills. The nature of the case studies themselves gives students an opportunity to develop their reasoning, problem-solving, and decision-making skills.

Finally, by requiring the instructors involved in the project to write up their findings for a journal, they are motivated to use a research methodology, thereby formalizing what professors and students engaged in using case studies already know--that this methodology engages students in a way that traditional lecture methodologies do not, that it causes students to invest themselves in their learning, that it gives them confidence in their own skills, and that it gives them the opportunity to develop more higher-order skills than in other engineering pedagogies. These studies have shown that through this research, many instructors and students have been exposed to the benefits of case studies. It is our goal that by disseminating this research in the Journal of STEM Education, other instructors will be inspired to experiment with case studies in their own classrooms.

Faculty members tend to shy away from using reform-oriented materials in their classrooms due to apprehension about how students will react to such unconventional instructional materials. Past studies have shown that faculty members need to be trained on a one-on-one basis to learn how to make full use of the special features of new instructional materials. Frequent contact with experts in the education field is also helpful, enabling them to amalgamate new and innovative multimedia instructional materials into education delivery and thus satisfy the requirements of ABET, industries, and society ${ }^{21,16}$. The dissemination model proposed in this paper takes other educators as partners in the dissemination process. The mini-grant and publication of the results encourages them to reflect on the implementation in the classroom and gather the advantages and disadvantages of using innovative pedagogies in the classrooms. We believe that such a model could be widely replicated, leading to more successful dissemination and evaluation of innovative instructional methodologies.

\section{Acknowledgements}

The work in this paper was sponsored by NSF DUE \#0442531. The opinions, findings, and conclusions or recommendations expressed in this paper are those of the authors and do not necessarily reflect the views of the National Science Foundation. The authors would like to thank each of the participants in this project for their hard work and effort. We would also like to thank Dr. Russell Pimmell, program director at NSF, for his support.

\section{References}

1. ABET. (2004). Engineering Change: A study of the impact of EC2000. Baltimore: ABET, Inc.

2. Abraham, N.S. \& Abulencia, J.P. (2010). Use of the LITEE Lorn Manufacturing Case Study in a Senior Chemical Engineering Unit Operations Laboratory, Journal of STEM Education: 
Innovations and Research. Accepted for publication.

3. Brumm, T.J., Ellerston, A., Fisher, D., \& Mickelson, S.K. (2004). Practicing Omega:

Addressing Learning Outcomes in an On-line Case Simulation. Proceedings of the 2004

American Society for Engineering Education Annual Conference \& Exposition.

4. Connolly, P. (2010). The Application of an Engineering Design and Information Systems

Case Study in a Senior Level Product Data Management Course, Journal of STEM

Education: Innovations and Research. Accepted for Publication.

5. Elrod, C. C., Murray, S.L., Flachsbart, B.B., Burgher, K.E., \& Foth, D.M. (2010). Utilizing

Multimedia Case Studies to Teach the Professional Side of Project Management, Journal of

STEM Education: Innovations and Research. Not yet published.

6. Fini, E. (2010). Incorporating a Real World Case Study into the Syllabus of a Senior

Construction Engineering Course, Journal of STEM Education: Innovations and Research.

Special Issue.

7. Fortenberry, N.L. (2000). An Examination of NSF's Programs in Undergraduate Education,

Journal of SMET Education: Innovations and Research, 1(1): 4-15.

8. Franchetti, M. (2010). Evaluation of the Effectiveness of the Integration of a LITEE Case Study for a Freshman Level Mechanical Engineering Course at The University of Toledo, Journal of STEM Education: Innovations and Research. Paper accepted for publication.

9. Fromm, E. (2003). The Changing Engineering Educational Paradigm, Journal of Engineering Education, 92(2): 113-121.

10. Mbarika, V., Bagarukayo, E., Hingorani, V., Stokes, S., Kourouma, M., \& Sankar, C. (2010). A Multi-Experimental Study on the Use of Multimedia Instructional Materials to Teach

Technical Subjects, Journal of STEM Education: Innovations and Research. Special Issue.

11. Mbarika, V., Sankar, C. S., \& Raju, P. K. (2003). Identification of factors that lead to perceived learning improvements for female students. IEEE Transactions on Education, 46(1): 26-36.

12. Mehta, S. \& Kou, Z. (2005). Designing Better Education in the Age of Globalization by

Building Partnerships, Connecting People, and Promoting Innovation. Proceedings of the 2005 American Society for Engineering Education Annual Conference \& Exposition.

13. National Academy of Engineering. (2004). The Engineer of 2020: Visions of engineering in

the new century. Washington, D.C.: National Academies Press.

14. National Science Foundation. (1996). Shaping the Future: New Expectations for

Undergraduate Education in Science, Mathematics, Engineering, and Technology, A Report

on its Review of Undergraduate Education by the Advisory Committee to the NSF,

Directorate of Education and Human Resources, NSF 96-139, National Science Foundation,

Arlington, VA.

15. Powlik, J.J. \& Sankar, C.S. (2001). Putting Education in the Picture, Journal of SMET

Education; Innovations and Research, 2(3\&4): 3-10.

16. Raju, P.K., Sankar, C.S., Halpin, G., and Halpin, G. (2002 ). Dissemination of Innovations

from an Education Research Project through Focused Workshops, Journal of SMET

Education and Research, 3(3\&4): 39-51.

17. Sankar, C.S. \& Raju, P.K. (2006). National Dissemination of Multi-Media Case Studies that

Bring Real-World Issues into Engineering Classrooms: Pilot Study. Proceedings of the 2006

American Society for Engineering Education Annual Conference \& Exposition.

18. Sankar, C.S., Varma, V., and Raju, P.K. (2008). Use of Case Studies in Engineering

Education: Assessment of Changes in Cognitive Skills, ASCE Journal of Professional Issues

in Engineering Education \& Practice, 134(3):287-296.

19. Splitt, F.G. (2003). The Challenge to Change: On Realizing the New Paradigm for

Engineering Education, Journal of Engineering Education, 92(2): 181-187.

20. Stanwick, P. (2010). Using Multimedia Content to Present Business Ethics: An Empirical

Study. Journal of STEM Education: Innovations and Research. Special Issue.

21. Wulf, A.A. (2002). The Urgency of Engineering Education Reform, Journal of SMET

Education: Innovations and Research, 3(3\&4): 3-9. 